\title{
STUDI KINETIKA VULKANISASI BELERANG PADA KOMPON KARET ALAM TANPA BAHAN PENGISI
}

\author{
Kinetics Study of Sulfur Vulcanization on Unfilled \\ Natural Rubber Compound \\ Adi CIFRIADI dan Asron F. FALAAH \\ Pusat Penelitian Karet \\ Jalan Salak No 1 Bogor 16151 \\ Email : cifriadi9748@gmail.com; fafa_rossoneri@yahoo.com
}

Diterima tanggal 27 Februari 2013 / Disetujui tanggal 18 April 2013

\begin{abstract}
The three kinds of sulfur vulcanization systems, conventional, semi-efficient, and efficient vulcanization, are grouped based on ratio sulfur and accelerator used. There are several parameters influencing the vulcanization such as vulcanization temperature, scorch time, vulcanization rate, and optimum time of vulcanization. Vulcanization rate on sulfur vulcanization can be measured by rheometer. Data of rheometer can be used to calculate reaction rate constant and activation energy by using Arrheniuss equation. The research studied kinetics reaction of sulfur vulcanization on unfilled natural rubber compound for three of sulfur vulcanization system at temperature $145^{\circ} \mathrm{C}, 150^{\circ} \mathrm{C}$, $160^{\circ} \mathrm{C}$, and $180^{\circ} \mathrm{C}$ with observation at torque modulus value between $10 \%$ - 90\% vulcanization process. Result in this research show that high rate constant reaction and low activation energy achieved by efficient vulcanization system
\end{abstract}

Keyword: Natural rubber, sulfur vulcanization, compound

\footnotetext{
Abstrak

Ketiga jenis sistem vulkanisasi belerang yaitu vulkanisasi konvensional, semi-efisien, dan efisien digolongkan berdasarkan perbandingan jumlah belerang dengan bahan pencepat yang digunakan. Beberapa parameter yang berpengaruh dalam vulkanisasi diantaranya temperatur vulkanisasi, waktu pra vulkanisasi, laju vulkanisasi, dan waktu optimum proses vulkanisasi. Untuk menentukan laju vulkanisasi pada sistem vulkanisasi belerang dapat diukur dengan menggunakan alat rheometer. Data hasil pengujian rheometer dapat digunakan untuk menghitung konstanta laju reaksi dan energi aktivasi berdasarkan persamaan Arrhenius. Penelitian ini melakukan studi tentang kinetika reaksi vulkanisasi belerang pada kompon karet alam tanpa bahan pengisi untuk ketiga sistem vulkanisasi belerang pada suhu $145^{\circ} \mathrm{C}, 150^{\circ} \mathrm{C}$, $160^{\circ} \mathrm{C}$, dan $180^{\circ} \mathrm{C}$ dengan pengamatan nilai
}

modulus torsi antara $10 \% \quad-\quad 90 \%$ proses vulkanisasi. Hasil penelitian menunjukkan bahwa konstanta laju reaksi paling tinggi dan energi aktivasi terendah dicapai oleh sistem vulkanisasi efisien.

Katakunci: Karet alam, vulkanisasi belerang, kompon

\section{PENDAHULUAN}

Dalam pembuatan barang jadi karet alam terdapat beberapa faktor yang mempengaruhi sifat fisiknya, diantaranya viskositas karet alam, sistem vulkanisasi, dan bahan kimia kompon. Bahan kimia tersebut mempunyai fungsi spesifik dan berpengaruh pada sifat, karakteristik pengolahan serta harga dari kompon karetnya. Kompon karet setelah mengalami vulkanisasi menggunakan bahan pemvulkanisasi akan membentuk jaringan tiga dimensi pada struktur molekul karet sehingga karet berubah sifat dari termoplastik menjadi stabil terhadap panas dengan perbaikan sifat elastisnya (Mark et al., 2005).

Pada saat vulkanisasi, rantai molekul karet dihubungkan oleh belerang sehingga membentuk ikatan silang antar rantai molekul karet. Beberapa ikatan silang yang dihasilkan tergantung pada kondisi pematangan (curing condition), waktu, temperatur, jumlah bahan kimia dalam kompon serta tipe vulkanisasi. Parameter selama vulkanisasi yang harus diperhatikan adalah waktu yang diperlukan untuk memulai vulkanisasi, laju vulkanisasi, lama proses vulkanisasi dan rasio jumlah antara belerang - bahan pencepat yang akan digunakan. Laju vulkanisasi pada 
vulkanisasi belerang dapat diamati dengan menggunakan alat rheometer.

Penggunaan jumlah belerang dan bahan pencepat memungkinkan pengaturan jenis dan jumlah ikatan silang, sehingga akan mempengaruhi sifat barang jadi karet yang dihasilkan. Sistem konvensional, sistem efisisen, dan sistem semi-efisien merupakan sistem vulkanisasi yang dikenal berdasarkan perbedaan konsentrasi belerang dengan bahan pencepat. Reaksi antara belerang dengan karet dalam proses vulkanisasi diasumsikan mengikuti kinetika reaksi orde satu yaitu:

Karet + belerang $\left(\mathrm{S}_{8}\right) \stackrel{\mathrm{k}}{\longrightarrow}$ Karet-Sx-Karet

Dimana k merupakan konstanta laju reaksi pada saat pematangan (cure) dan bahan pencepat berperan sebagai katalis (Nah et al., 2001).

Kinetika kimia adalah bagian ilmu kimia fisika yang mempelajari laju reaksi kimia, faktor-faktor yang mempengaruhinya, serta penjelasan hubungannya terhadap mekanisme reaksi. Kinetika kimia disebut juga dinamika kimia, karena adanya gerakan molekul, elemen atau ion dalam mekanisme reaksi dan laju reaksi sebagai fungsi waktu. Mekanisme reaksi dapat diperkirakan dengan bantuan pengamatan dan pengukuran besaran termodinamika suatu reaksi. Dengan mengamati arah jalannya reaktan maupun produk suatu sistem dapat diketahui nilai laju reaksi tersebut.

Laju reaksi vulkanisasi dapat diasumsikan dengan perbandingan konsentrasi sulfur itu sendiri dengan menggunakan persamaan berikut :

$$
\ln \frac{[\mathrm{St}]}{\left[\mathrm{S}_{\mathrm{o}}\right]}=-\mathrm{kt}
$$

dimana:

$$
\begin{aligned}
{\left[\mathrm{S}_{0}\right]=} & \text { konsentrasi awal sulfur } \\
{[\mathrm{St}]=} & \text { konsentrasi sulfur sesudah } \\
& \text { beberapawaktu }(\mathrm{t})
\end{aligned}
$$

Menurut Fujimoto (1981), persamaan kinetika reaksi orde satu dapat ditulis dengan persamaan berikut :

$$
\ln (\mathrm{a}-\mathrm{x})=-\mathrm{kt}+\ln \mathrm{a}
$$

Nilai a merupakan konsentrasi awal reaktan, sedangkan nilai $\mathrm{x}$ adalah jumlah reaktan yang direaksikan pada waktu t. Nilai $\mathrm{k}$ adalah kontanta laju reaksi orde satu. Reaksi vulkanisasi karet alam dapat diamati melalui data modulus torsi pada rheometer, sehingga modulus torsi dapat dianalogikan dengan persamaan :

$(\mathrm{a}-\mathrm{x})=\mathrm{M}_{\mathrm{H}}-\mathrm{M}_{\mathrm{t}}$

$\mathrm{a}=\mathrm{M}_{\mathrm{H}}-\mathrm{M}_{\mathrm{L}}$

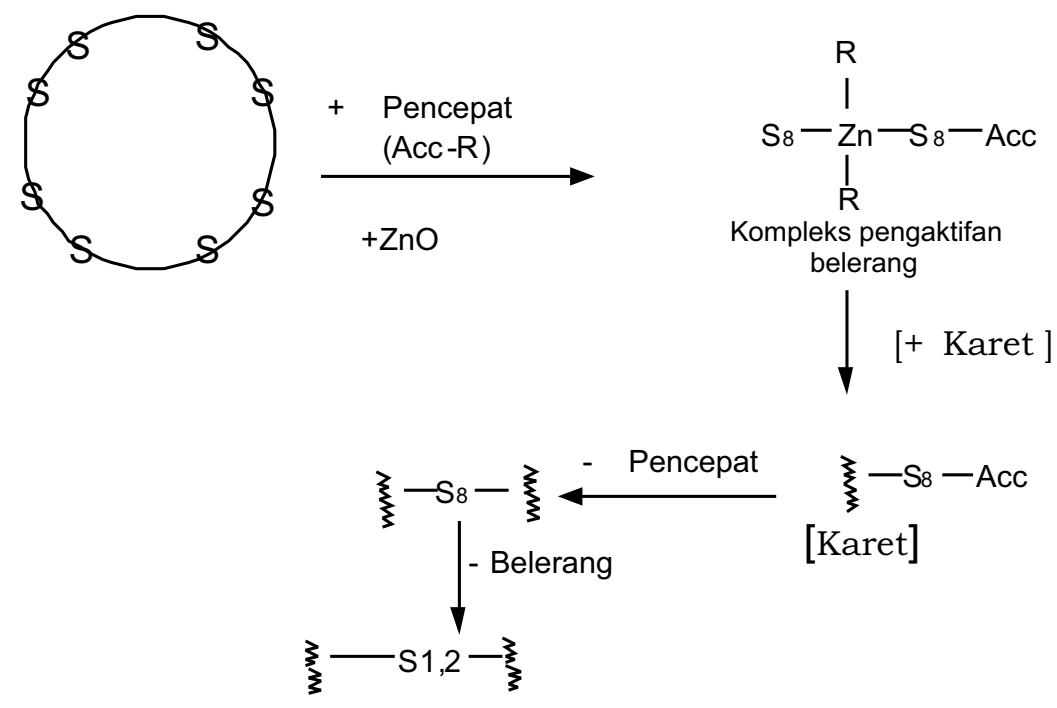

Gambar 1. Mekanisme vulkanisasi belerang,

Figure 1. Mechanism of sulfur vulcanization, Sumber (Source): Honggokusumo,1994 
Nilai $\mathrm{M}_{\mathrm{H}}$ dan $\mathrm{M}_{\mathrm{L}}$ merupakan modulus torsi maksimum dan minimum, sedangkan $\mathrm{M}_{\mathrm{t}}$ adalah modulus torsi pada waktu $\mathrm{t}$. Persamaan 2, 3 dan 4 dapat diuraikan sebagai berikut :

$$
\begin{aligned}
& \ln \left(\mathrm{M}_{\mathrm{H}}-\mathrm{M}_{\mathrm{t}}\right)=-\mathrm{k} \cdot \mathrm{t}+\ln \left(\mathrm{M}_{\mathrm{H}}-\mathrm{M}_{\mathrm{L}}\right) \\
& \ln \left(\mathrm{M}_{\mathrm{H}}-\mathrm{M}_{\mathrm{t}}\right)-\ln \mathrm{M}_{\mathrm{H}}-\mathrm{M}_{\mathrm{L}}=-\mathrm{kt}
\end{aligned}
$$

Apabila persamaan 5 dibuat kurva hubungan antara $\ln \left(\mathrm{M}_{\mathrm{H}}-\mathrm{M}_{\mathrm{t}}\right)$ dengan waktu $\mathrm{t}$, nilai $\mathrm{k}$ merupakan slope kurva tersebut (Aprem et al, 2003). Data yang diperoleh dari rheometer seperti modulus torsi maksimum dan minimum digunakan untuk menghitung konstanta laju reaksi dan energi aktivasi dengan menggunakan persamaan Arrhenius. Energi aktivasi adalah sejumlah energi minimum yang diperlukan oleh suatu zat untuk dapat bereaksi hingga terbentuk zat baru. Nilai $\mathrm{k}$ yang diperoleh dapat digunakan untuk menghitung energi aktivasi reaksi orde 1 melalui persamaan Arrhenius sebagai berikut :

$$
\begin{aligned}
& \mathrm{k}=\mathrm{A} \exp (-\mathrm{Ea} / \mathrm{RT}) \\
& \ln \mathrm{k}=\ln [\mathrm{A}]-\frac{\mathrm{Ea}}{\mathrm{R}} \cdot \frac{1}{\mathrm{~T}}
\end{aligned}
$$

Ea adalah energi aktivasi, sedangkan $\mathrm{R}$ adalah tetapan gas sebesar $8,31 \mathrm{~J} / \mathrm{molK}$. Persamaan (7) dapat analogikan menjadi suatu persamaan garis linier yaitu :

$$
y=a x+b
$$

$$
\text { dimana } \mathrm{y}=\ln \mathrm{k} ; \mathrm{a}=-\frac{E a}{R} ; \mathrm{x}=\frac{1}{T} ; \mathrm{b}=\ln [\mathrm{A}]
$$

Penelitian ini bertujuan untuk memperkirakan konstanta laju reaksi dan energi aktivasi beberapa sistem vulkanisasi belerang berdasarkan karakteristik vulkanisasi (characteristic vulcanization) pada kompon karet alam tanpa bahan pengisi.

\section{BAHAN DAN METODE}

Penelitian ini dilakukan di Pabrik Percobaan dan Laboratorium Fisika Pusat Penelitian Karet Bogor pada periode bulan Agustus sampai dengan bulan November tahun 2012. Bahan kimia yang digunakan untuk pembuatan kompon karet dalam penelitian ini adalah karet SIR 20, ZnO (zinc oxide), asam stearat, TBBS sebagai bahan pencepat karena merupakan jenis pencepat primer yang memberikan waktu pravulkanisasi yang lambat dengan respon cepat - ditunda, dan belerang (sulfur) sebagai bahan pemvulkanisasi. Karet SIR 20 yang digunakan memiliki nilai kadar abu, kadar zat menguap (volatile matter), kadar kotoran, kadar nitrogen, PRI, dan Po berturut-turut adalah sebagai berikut : 0,85\%; 0,35\%; 0,06\%; 0,46\%; 61,8; dan 34 .

\section{Pembuatan Kompon}

Formulasi kompon karet yang dibuat terdiri dari beberapa sistem vulkanisasi yaitu konvensional, semi-efisien dan efisien. Proses pembuatan kompon skala laboratorium dilakukan dengan mengacu pada prosedur baku ASTM-D-3182 pada mesin giling terbuka (open mill) dengan bobot bahan sebanyak 3 kali phr (part per hundred rubber), bagian seratus karet). Formulasi kompon dalam satuan phr disajikan pada Tabel 1.

\section{Vulkanisasi Kompon Karet}

Kompon karet divulkanisasi dengan menggunakan mesin press hidraulik merek KMC yang tersedia di Pabrik Percobaan Pusat Penelitian Karet Bogor. Mesin press hidraulik diatur pada kondisi tekanan 150 psi, dengan waktu yang ditetapkan menurut hasil uji karakteristik vulkanisasi. Suhu vulkanisasi ditetapkan sebagai variabel percobaan yaitu $145,150,160$ dan $180^{\circ} \mathrm{C}$.

\section{Perhitungan Laju Reaksi dan Energi Aktivasi}

Pada penelitian ini dilakukan pengamatan terhadap karakteristik vulkanisasi pada variasi suhu vulkanisasi yaitu $145^{\circ} \mathrm{C}, 150^{\circ} \mathrm{C}, 160^{\circ} \mathrm{C}$ dan $180^{\circ} \mathrm{C}$ melalui rheometer untuk mengetahui waktu vulkanisasi masing-masing formula, torsi maksimum $\left(\mathrm{M}_{\mathrm{H}}\right)$, torsi minimum $\left(\mathrm{M}_{\mathrm{L}}\right)$ dan torsi pada waktu t. Pada penelitian ini pula dilakukan perhitungan untuk mengetahui besarnya laju reaksi dan energi aktivasi dari masing-masing formula. 
Tabel 1. Formulasi kompon percobaan

Table 1. Formulation of experiment compound

\begin{tabular}{lcccccc}
\hline \multirow{2}{*}{$\begin{array}{c}\text { Bahan } \\
\text { Materials }\end{array}$} & \multicolumn{7}{c}{$\begin{array}{c}\text { Kompon } \\
\text { Compound }\end{array}$} \\
\cline { 2 - 7 } & $\mathrm{CV} 1$ & $\mathrm{CV} 2$ & $\mathrm{SE} 1$ & $\mathrm{SE} 2$ & $\mathrm{EV} 1$ & $\mathrm{EV} 2$ \\
\hline SIR 20 & 100 & 100 & 100 & 100 & 100 & 100 \\
ZnO & 6 & 6 & 6 & 6 & 6 & 6 \\
Asam Stearat & 0,5 & 0,5 & 0,5 & 0,5 & 0,5 & 0,5 \\
TBBS & 0,7 & 0,7 & 1,5 & 1,5 & 2,5 & 2,5 \\
Sulfur & 2,5 & 3,5 & 1 & 1,7 & 0,5 & 0,35 \\
\hline
\end{tabular}

$\mathrm{CV}=$ Sistem vulkanisasi konvensional (Conventional vulcanization system)

$\mathrm{SE}=$ Sistem vulkanisasi semi-efisien (Semi-efficient vulcanization system)

$\mathrm{EV}=$ Sistem vulkanisasi efisien (efficient vulcanization system)

\section{HASIL DAN PEMBAHASAN}

\section{Laju Reaksi dan Energi Aktivasi}

Suatu reaksi kimia apabila ditinjau dari segi teknik tentunya diinginkan laju reaksi yang sangat tinggi dengan menggunakan konsentrasi reaktan yang kecil serta diperoleh hasil produk yang besar dan biaya yang rendah. Perhitungan laju reaksi pada vulkanisasi kompon karet telah menggambarkan cepat atau lambatnya waktu yang diperlukan untuk merubah kompon karet (reaktan) menjadi vulkanisat (produk). Menurut Levenspiel (1999), pada dasarnya reaksi kimia tergantung pada suhu dan komposisi, sehingga untuk laju reaksi kimia dapat ditulis dengan :

$$
r 1=f_{1} \text { (suhu), } f_{2} \text { (komposisi) }
$$

Hasil uji karakteristik vulkanisasi kompon percobaan yang divulkanisasi pada suhu $145^{\circ} \mathrm{C}, 150^{\circ} \mathrm{C}, 160^{\circ} \mathrm{C}$, dan $180^{\circ} \mathrm{C}$ yang diperoleh dari rheometer disajikan dalam Tabel 2. Dari data tersebut diperoleh nilai modulus torsi maksimum $\left(\mathrm{M}_{\mathrm{H}}\right)$, modulus torsi minimum $\left(\mathrm{M}_{\mathrm{L}}\right)$, waktu optimum $\left(\mathrm{t}_{90}\right)$ dan waktu pra vulkanisasi $\left(\mathrm{tS}_{2}\right)$. Kompon dengan formulasi menggunakan sistem vulkanisasi efisien (EV) lebih cepat mencapai waktu optimum $\left(t_{90}\right)$, karena kompon tersebut memiliki jumlah bahan pencepat lebih banyak dibanding kompon dengan menggunakan sistem vulkanisasi konvensional dan semi-efisien.

Nilai modulus torsi maksimum $\left(\mathrm{M}_{\mathrm{H}}\right)$ yang tinggi dicapai oleh kompon yang menggunakan sistem vulkanisasi konvensional (CV), karena jumlah belerang pada kompon konvensional lebih banyak dibanding dengan kompon yang menggunakan sistem vulkanisasi semiefisien dan efisien. Jumlah belerang yang banyak, menyebabkan jumlah ikatan silang (crosslink) semakin banyak yang terbentuk. Hal tersebut menyebabkan peningkatan nilai kekerasan (hardness) sehingga nilai modulus torsi akan meningkat. Kurva hasil uji karakteristik vulkanisasi kompon disajikan pada Gambar 2.

Perhitungan konstanta laju reaksi (k) menggunakan persamaan 5. Pada penelitian ini nilai $\mathrm{M}_{\mathrm{t}}$ yang digunakan yaitu pada rentang $10 \%$ - 90\% vulkanisasi. Dari persamaan tersebut kemudian diperoleh kurva hubungan antara $\ln \left(\mathrm{M}_{\mathrm{H}^{-}} \mathrm{M}_{\mathrm{t}}\right)$ dengan waktu (t). Kemiringan atau slope dari kurva tersebut merupakan nilai k. Kurva hubungan antara ln $\left(\mathrm{M}_{\mathrm{H}}-\mathrm{M}_{\mathrm{t}}\right)$ dengan waktu $\mathrm{t}$ pada suhu vulkanisasi 145, 150, 160 dan $180{ }^{\circ} \mathrm{C}$ disajikan dalam Gambar 3.

Kurva pada Gambar 3 menunjukkan pola yang hampir sama pada masing-masing formula pada beberapa suhu vulkanisasi. Hasil penelitian menunjukkan bahwa semakin tinggi suhu vulkanisasi maka konstanta laju reaksi (k) akan meningkat. Nilai k untuk reaksi vulkanisasi paling cepat adalah pada sistem vulkanisasi efisien (EV). Nilai k sistem vulkanisasi efisien (EV1) 3 kali lebih besar dari nilai $\mathrm{k}$ sistem vulkanisasi konvensional (CV1 dan CV2). Nilai $\mathrm{k}$ pada sistem vulkanisasi semi-efisien (SE) lebih kecil dibanding vulkanisasi efisien (EV), namun 2 kali lebih besar dibanding vulkanisasi konvensional (CV1 dan CV 2). 
Tabel 2. Data uji karakteristik vulkanisasi

Table 2. Test data of vulcanization characteristics

\begin{tabular}{|c|c|c|c|c|c|c|}
\hline \multirow[t]{2}{*}{$\begin{array}{c}\text { Karakteristik pematangan } \\
\text { Curing characteristics }\end{array}$} & \multicolumn{6}{|c|}{$\begin{array}{l}\text { Kompon } \\
\text { Compound }\end{array}$} \\
\hline & CV1 & CV2 & SE1 & SE2 & EV1 & EV2 \\
\hline \multicolumn{7}{|c|}{$\begin{array}{l}\text { Temperatur vulkanisasi pada } 145^{\circ} \mathrm{C} \\
\text { Vulcanization temperature at } 145^{\circ} \mathrm{C}\end{array}$} \\
\hline$S$ Max - S Min', kg-cm & 5,44 & 5,29 & 3,67 & 4,9 & 2,67 & 1,84 \\
\hline$S \max \left(M_{H}\right), \mathrm{kg}-\mathrm{cm}$ & 5,71 & 5,76 & 4,07 & 5,28 & 2,98 & 2,23 \\
\hline$S \min \left(M_{L}\right), \mathrm{kg}-\mathrm{cm}$ & 0,27 & 0,47 & 0,4 & 0,38 & 0,31 & 0,39 \\
\hline$t_{90}, \min : \min . \mathrm{sec}$ & $9: 26$ & $10: 03$ & $4: 40$ & $5: 29$ & $2: 55$ & $5: 23$ \\
\hline Scorch time ts2, min.sec & 2,57 & 2,37 & 2,27 & 1,55 & 2,03 & - \\
\hline \multicolumn{7}{|c|}{$\begin{array}{l}\text { Temperatur vulkanisasi pada } 150^{\circ} \mathrm{C} \\
\text { Vulcanization temperature at } 150^{\circ} \mathrm{C}\end{array}$} \\
\hline$S$ Max - S Min', kg-cm & 5,14 & 4,96 & 3,68 & 4,89 & 2,59 & 1,78 \\
\hline$S \max \left(M_{H}\right), \mathrm{kg}-\mathrm{cm}$ & 5,4 & 5,37 & 4,03 & 5,22 & 2,89 & 2,14 \\
\hline$S \min \left(M_{L}\right), \mathrm{kg}-\mathrm{cm}$ & 0,26 & 0,41 & 0,35 & 0,33 & 0,3 & 0,36 \\
\hline$t_{90}, \min : \min . s e c$ & $6: 49$ & $7: 26$ & $3: 03$ & $3: 26$ & 2 & $3: 23$ \\
\hline Scorch time ts2, min.sec & 2,23 & 2,16 & 1,46 & 1,27 & 1,34 & - \\
\hline \multicolumn{7}{|c|}{$\begin{array}{l}\text { Temperatur vulkanisasi pada } 160^{\circ} \mathrm{C} \\
\text { Vulcanization temperature at } 160^{\circ} \mathrm{C}\end{array}$} \\
\hline$S$ Max - S Min', kg-cm & 4,97 & 5,02 & 3,48 & 4,91 & 2,41 & 1,54 \\
\hline$S \max \left(M_{H}\right), \mathrm{kg}-\mathrm{cm}$ & 5,22 & 5,45 & 3,82 & 5,24 & 2,68 & 1,87 \\
\hline$S \min \left(M_{L}\right), \mathrm{kg}-\mathrm{cm}$ & 0,25 & 0,43 & 0,34 & 0,33 & 0,27 & 0,33 \\
\hline$t_{90}, \min : \min . s e c$ & $3: 58$ & $4: 16$ & $1: 52$ & $2: 04$ & $1: 19$ & $2: 15$ \\
\hline Scorch time ts2, min.sec & 1,32 & 1,24 & 1,12 & 0,58 & 1,09 & - \\
\hline \multicolumn{7}{|c|}{$\begin{array}{l}\text { Temperatur vulkanisasi pada } 180^{\circ} \mathrm{C} \\
\text { Vulcanization temperature at } 180^{\circ} \mathrm{C}\end{array}$} \\
\hline$S \operatorname{Max}-S$ Min', kg-cm & 4,17 & 4,6 & 2,89 & 4,39 & 1,31 & 0,7 \\
\hline$S \max \left(M_{H}\right), \mathrm{kg}-\mathrm{cm}$ & 4,43 & 5,04 & 3,24 & 4,74 & 1,6 & 0,96 \\
\hline$S \min \left(M_{L}\right), \mathrm{kg}-\mathrm{cm}$ & 0,26 & 0,44 & 0,35 & 0,35 & 0,29 & 0,26 \\
\hline$t_{90}, \min : \min . s e c$ & $1: 39$ & $1: 46$ & $0: 52$ & $0: 55$ & $0: 50$ & $1: 14$ \\
\hline Scorch time ts2, min.sec & 0,49 & 0,45 & 0,42 & 0,34 & - & - \\
\hline
\end{tabular}

dengan :

$\mathrm{S}=$ Modulus torsi

$\mathrm{t}=$ waktu 


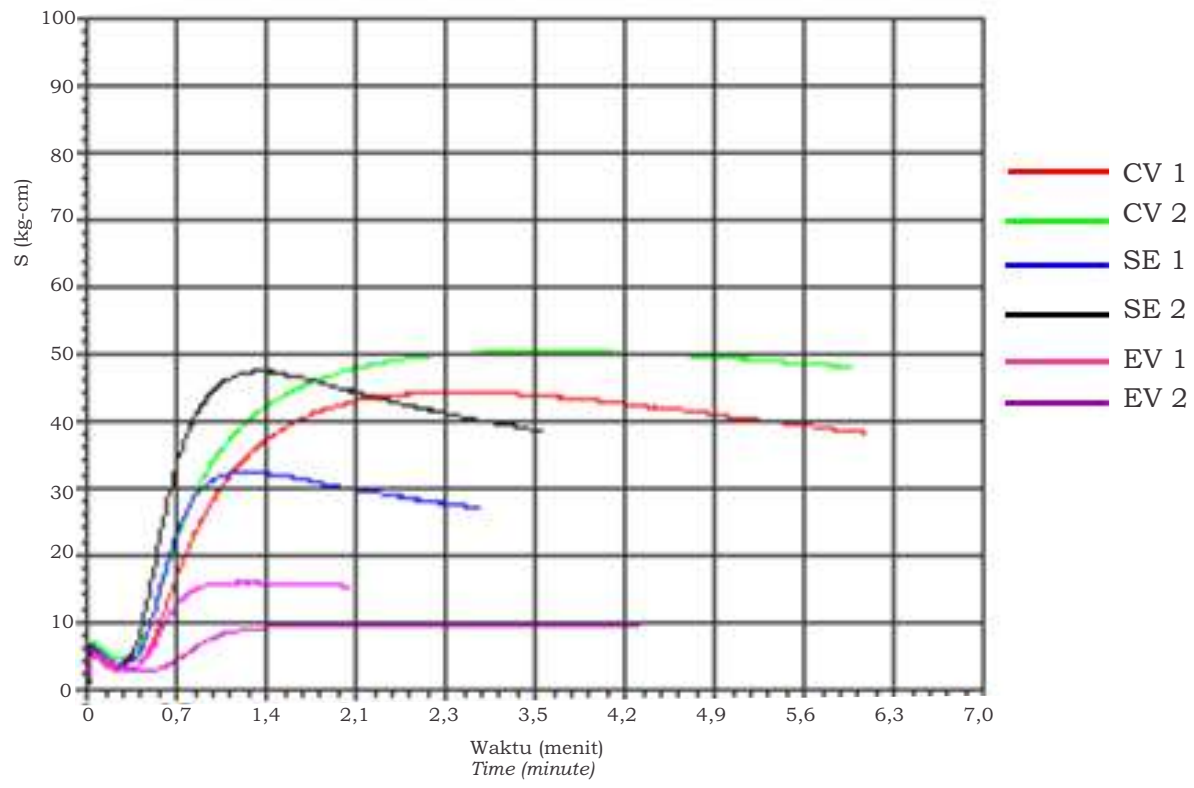

Gambar 2. Contoh kurva rheometer pada suhu vulkanisasi $150^{\circ} \mathrm{C}$

Figure 2. Example of rheometer curve at vulcanization temperature $150^{\circ} \mathrm{C}$

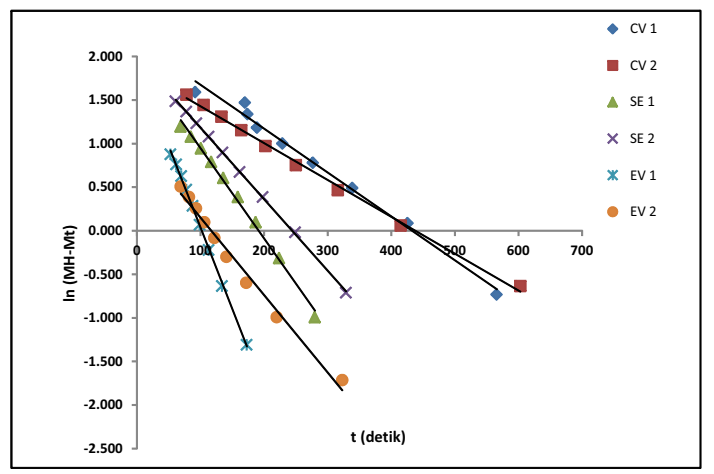

(a)

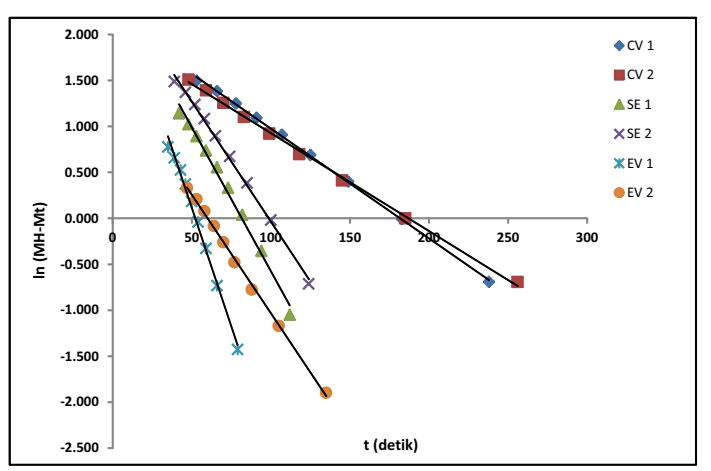

(d)

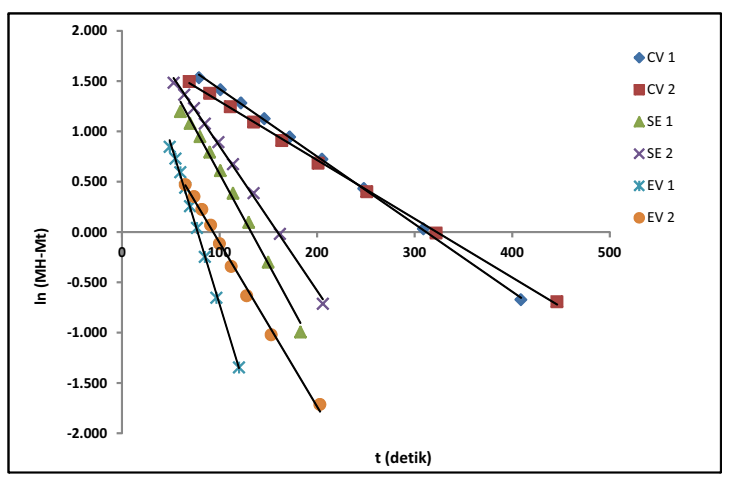

(b)

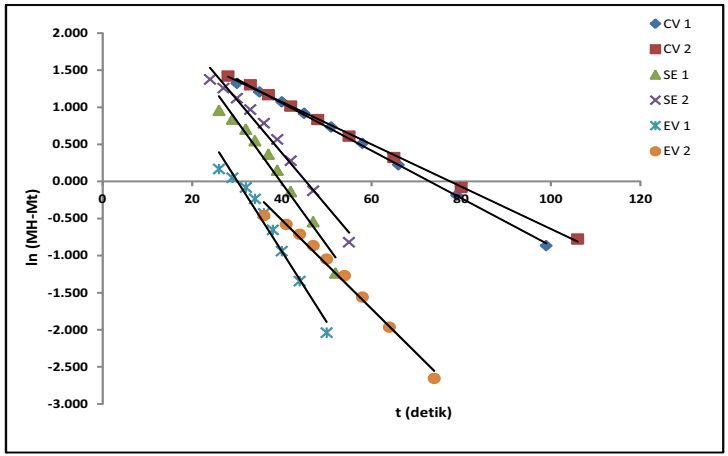

(d)

Keterangan (notes) :

(a) suhu vulkanisasi $145^{\circ} \mathrm{C}$; (b) suhu vulkanisasi $150^{\circ} \mathrm{C}$; (c) suhu vulkanisasi $160^{\circ} \mathrm{C}$; (d) suhu vulkanisasi $180^{\circ} \mathrm{C}$

(a) vulcanization temperature $145^{\circ} \mathrm{C}$; (b) vulcanization temperature $150^{\circ} \mathrm{C}$; (c) vulcanization temperature $145^{\circ} \mathrm{C}$; vulcanization temperature $180^{\circ} \mathrm{C}$

Gambar 3. Kurva hubungan $\ln \left(\mathrm{M}_{\mathrm{H}}-\mathrm{M}_{\mathrm{t}}\right)$ vs waktu (t)

Figure 3. Relation Curves $\ln \left(M_{H^{-}} M_{t}\right)$ vs time (t) 
Sistem vulkanisasi efisien (EV) memiliki jumlah bahan pencepat lebih banyak dari pada belerang, sehingga proses vulkanisasi akan berlangsung lebih cepat dibandingkan sistem vulkanisasi konvensional (CV) dan semi-efisien (SE). Nilai $\mathrm{k}$ disajikan dalam Tabel 3.

Selain faktor suhu, laju reaksi kimia juga dipengaruhi oleh adanya bahan yang disebut katalis. Katalis dapat berfungsi untuk mempercepat reaksi hingga beberapa kali lipat atau pula memperlambat reaksi (negative catalyst) (Levenspiel, 1999). Pada reaksi vulkanisasi bahan pencepat dapat dikatakan sebagai katalis karena dapat meningkatkan laju vulkanisasi. Bahan pencepat dapat memperpendek waktu vulkanisasi dari beberapa jam menjadi beberapa menit atau detik pada suhu vulkanisasi tinggi (Gupta, 1978).

Suatu reaksi kimia dapat berlangsung endoterm maupun eksoterm. Reaksi endoterm spontan terjadi apabila energi yang diperlukan cukup diambil dari lingkungan saja. Namun banyak reaksi yang memerlukan perlakuan panas untuk dapat bereaksi, salah satunya adalah reaksi vulkanisasi yang membentuk ikatan silang antar karet dan belerang. Oleh karena itu untuk memulai reaksi vulkanisasi perlu penambahan energi berupa panas, karena tak cukup hanya dengan mengambil energi dari lingkungan saja. Keseluruhan energi untuk bereaksi itulah yang dinamakan energi aktivasi.

Pada percobaan telah dilakukan perhitungan energi aktivasi masing-masing kompon dengan sistem vulkanisasi yang berbeda dan suhu vulkanisasi yang telah ditetapkan. Perhitungan energi aktivasi beberapa sistem vulkanisasi menggunakan persamaan 7 , selanjutnya dari persamaan 7 kemudian diinterpertasikan dalam sebuah persamaan garis (8) sehingga terbentuk kurva hubungan antara konstanta laju reaksi (ln k) dengan suhu vulkanisasi $(1000 / T)$. Energi aktivasi (Ea) dapat dihitung dari kemiringan (slope) pada kurva tersebut. Contoh kurva hubungan antara konstanta laju reaksi dengan suhu vulkanisasi disajikan dalam Gambar 4, sedangkan nilai energi aktivasi masing-masing formula disajikan dalam Tabel 4.

Tabel 4. memperlihatkan kompon dengan sistem vulkanisasi efisien (EV1 dan EV 2) menghasilkan energi aktivasi yang lebih kecil dibandingkan energi aktivasi sistem vulkanisasi konvensional (CV) maupun semi-efisien (SE), hal ini dikarenakan sistem vulkanisasi efisien (EV) mencapai waktu optimum $\left(\mathrm{T}_{90}\right)$ paling cepat, sehingga energi yang dibutuhkan untuk reaksi vulkanisasi lebih kecil.

Pada vulkanisasi konvensional energi aktivasi cukup besar karena pencapaian waktu optimum lebih lama dan jumlah bahan pencepat lebih sedikit dari jumlah belerang. Jumlah belerang yang banyak menyebabkan jumlah ikatan silang yang terbentuk cukup banyak dan derajat vulkanisasi meningkat, sehingga energi aktivasi menjadi lebih besar. Ikatan silang yang terbentuk pada sistem vulkanisasi konvensional (CV) merupakan ikatan silang polisulfida yang mengandung banyak atom belerang (Suparto \& Santosa, 2002). Selama proses pemanasan dan pemasakan kompon, ikatan polisulfida akan putus membentuk ikatan silang yang lebih pendek dan semakin

Tabel 3. Nilai $\mathrm{k}$ pada suhu vulkanisasi $145^{\circ} \mathrm{C}, 150^{\circ} \mathrm{C}, 160^{\circ} \mathrm{C}$ dan $180^{\circ} \mathrm{C}$

Table 3. $k$ value at vulcanization temperature $145^{\circ} \mathrm{C}, 150^{\circ} \mathrm{C}, 160^{\circ} \mathrm{C}$ and $180^{\circ} \mathrm{C}$

\begin{tabular}{ccccc}
\hline \multirow{2}{*}{$\begin{array}{c}\text { Kompon } \\
\text { Compound }\end{array}$} & \multicolumn{4}{c}{$\begin{array}{c}\text { Konstanta laju reaksi (k), detik } \\
\text { Reaction rate constant, second }{ }^{-1}\end{array}$} \\
\cline { 2 - 5 } CV1 & $145^{\circ} \mathrm{C}$ & $150^{\circ} \mathrm{C}$ & $160^{\circ} \mathrm{C}$ & $180^{\circ} \mathrm{C}$ \\
\hline CV2 & 0,005 & 0,006 & 0,011 & 0,032 \\
SE1 & 0,004 & 0,005 & 0,010 & 0,028 \\
SE2 & 0,010 & 0,017 & 0,031 & 0,083 \\
EV1 & 0,008 & 0,014 & 0,026 & 0,071 \\
EV2 & 0,018 & 0,031 & 0,051 & 0,095 \\
\hline
\end{tabular}




\section{Cifriadi dan Falaah}

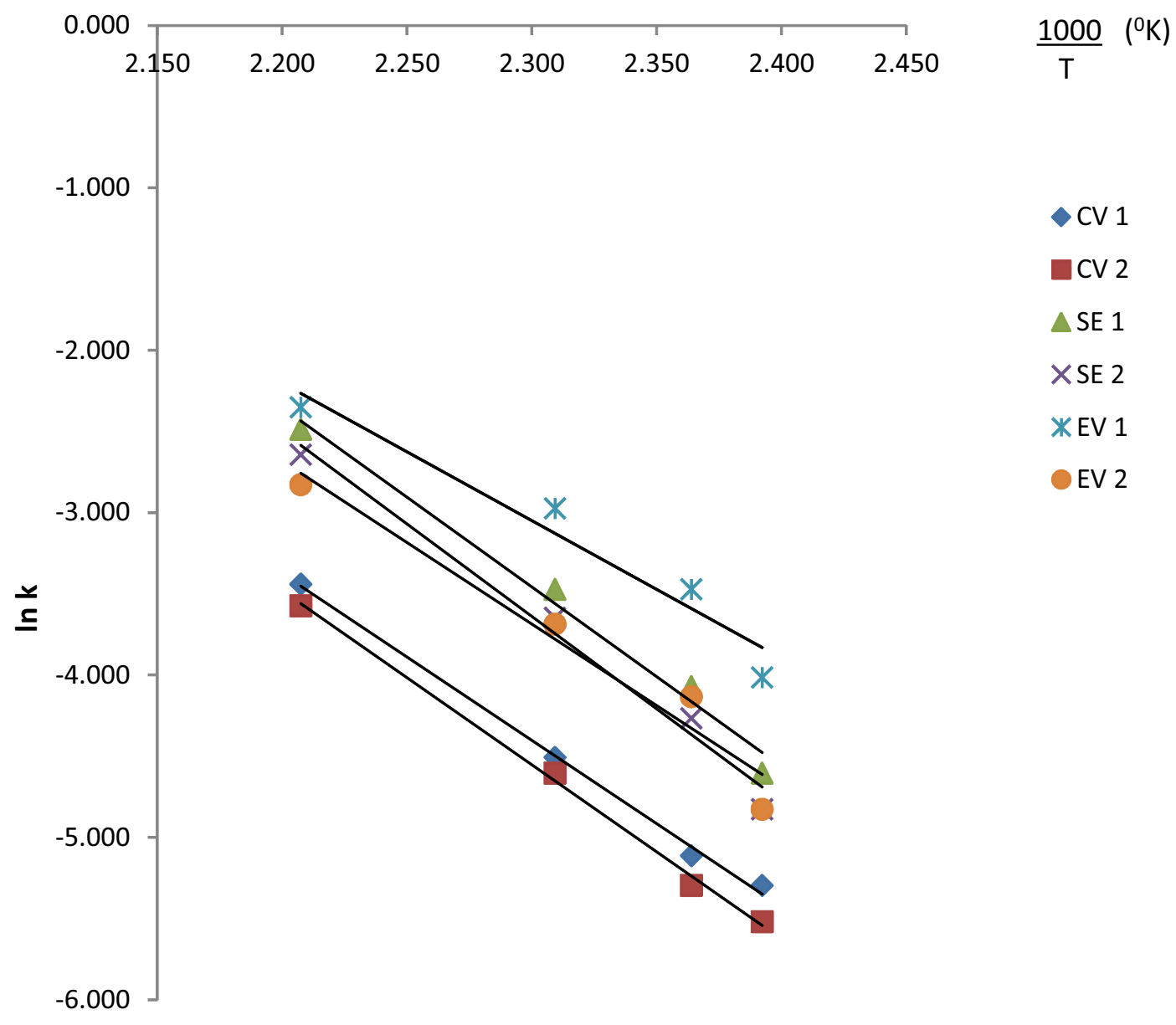

Gambar 4. Kurva hubungan konstanta laju reaksi vs suhu vulkanisasi

Figure 4. Relation curves of reaction rate constant $v$ s vulcanization temperature

Tabel 4. Nilai energi aktivasi kompon

Table 4. Activation energy value of compound

\begin{tabular}{ccccc}
\hline $\begin{array}{c}\text { Kompon } \\
\text { Compound }\end{array}$ & $\begin{array}{c}\text { Persamaan kurva } \\
\text { Curves equation }\end{array}$ & $\begin{array}{c}\text { Slope } \\
\text { Slope }\end{array}$ & $\mathrm{R}(\mathrm{J} / \mathrm{mol} \mathrm{K})$ & $\begin{array}{c}\text { Energi aktivasi }(\mathrm{kJ} / \mathrm{mol}) \\
\text { Activation energy }(\mathrm{kJ} / \mathrm{mol})\end{array}$ \\
\hline CV1 & $\mathrm{y}=-10,25 \mathrm{x}+19,18$ & 10,25 & 8,31 & 85,18 \\
CV2 & $\mathrm{y}=-10,71 \mathrm{x}+20,09$ & 10,71 & 8,31 & 89,00 \\
SE1 & $\mathrm{y}=-11,05 \mathrm{x}+21,97$ & 11,05 & 8,31 & 91,83 \\
SE2 & $\mathrm{y}=-11,38 \mathrm{x}+22,54$ & 11,38 & 8,31 & 94,57 \\
EV1 & $\mathrm{y}=-8,468 \mathrm{x}+16,42$ & 8,47 & 8,31 & 70,37 \\
EV2 & $\mathrm{y}=-10,03 \mathrm{x}+19,38$ & 10,03 & 8,31 & 83,35 \\
\hline
\end{tabular}


banyak pemutusan ikatan silang dapat menyebabkan energi aktivasi yang diperlukan semakin besar.

Penggunaan jumlah bahan pencepat yang bervariasi pada kompon percobaan telah menghasilkan energi aktivasi yang berbeda. Penelitian ini hanya menggunakan satu jenis bahan pencepat yaitu TBBS sehingga untuk bahan pencepat jenis lain energi aktivasi yang dihasilkan akan berbeda karena setiap bahan pencepat mempunyai kelebihan masing-masing, namun mempunyai fungsi yang sama untuk mempercepat reaksi vulkanisasi. Oleh karena itu dalam memilih bahan pencepat yang digunakan harus mempertimbangkan beberapa faktor seperti umur bahan pada saat disimpan, sensitivitas bahan terhadap kelembaban udara, kecepatan dalam proses vulkanisasi dan pengaruh terhadap sifat akhir produk (Ciesielski, 1999).

\section{KESIMPULAN DAN SARAN}

Konstanta laju reaksi dan energi aktivasi pada proses vulkanisasi dipengaruhi suhu reaksi, bahan pencepat serta beberapa faktor lain seperti konsentrasi pereaksi, faktor tumbukan, luas permukan partikel. Bahan pencepat dapat mempercepat laju reaksi dan menurunkan energi aktivasi. Penelitian ini menggunakan bahan pencepat TBBS yang menghasilkan laju reaksi paling cepat dan energi aktivasi paling rendah pada kompon dengan sistem vulkanisasi efisien (EV1). Penggunaan bahan pencepat selain TBBS diperkirakan menghasilkan nilai yang berbeda, namun fungsi bahan pencepat tetap sama. Penelitian ini perlu dilakukan pengujian sulfur bebas dan sulfur terikat sehingga diperoleh data jumlah sulfur yang bebas dan sulfur terikat dalam vulkanisat untuk menghitung laju reaksi vulkanisasi dan energi aktivasi yang dapat digunakan sebagai pembanding perhitungan laju reaksi dan energi aktivasi dengan menggunakan data dari rheometer.

\section{DAFTAR PUSTAKA}

Aprem, A.S., S. Thomas, K. Joseph, N. M. Barkoula, and J. K. Kocsis. 2003. Sulphur vulcanization of styrene butadiene rubber using new binary accelerator systems. Journal of Elastomers And Plastics, 35: 29-55.
ASTM International. 2007. Standard practice for rubber-materials, equipment, and procedures for mixing standard compound and preparing, standar vulcanized sheets. ASTM D.3182. West Conshohocken, Pennsylvania: American Society for Testing and Materials International.

Ciesielski, A. 1999. An Introduction to Rubber Technology. Rapra Technology Limited. Shropshire. p.35.

Fujimoto, K., T. Nishi and T. Okamoto. 1981. Devulcanisation of NB Based Latex Products For Tyre Applications. International Polymer Science and Technology, 8(8): 29-30.

Gupta, Rajendra K. 1978. Rubber technology and manufacture. Small Business Publication. New Delhi.

Honggokusumo, Suharto. 1994. Sistem vulkanisasi, Dalam kumpulan makalah kursus pengolahan barang jadi karet. Balai Penelitian Teknologi Karet. Bogor.

Levenspiel, Octave. 1999. Chemical reaction engineering. John Wiley \& Sons Inc. New York.

Mark, J.E., B. Erman and F. R. Eirich. 2005. Science and technology of rubber 3rd edition, Elsevier Academic Press., United States of America, p: 321 366.

Nah, Changwoon., W.D. Kim, and S.Lee. 2001. Effects of carbon black content and vulcanization type on cure characteristics and dynamic mechanical property of styrenebutadiene rubber compound. Korea Polymer Journal, 9(3):157-163.

Santosa, Agus M dan D. Suparto. 2002. Kimia dan teknologi vulkanisasi. Dalam kumpulan makalah kursus teknologi barang jadi karet. Balai Penelitian Teknologi Karet. Bogor. 